\title{
Pemakaian Kata Sapaan (Taishoushi) di Dunia Kerja Perhotelan: Analisis Percakapan Drama TV dan Film Jepang
}

\author{
The Usage of Term of Address (Taishoushi) in Hospitality Workplace: \\ An Analysis of Conversations in Japanese TV Drama and Movie
}

\author{
Dyah Martanti Indah Pratiwi \\ TECHNO RYOWA LTD. Perwakilan Jakarta \\ dyah.mip@gmail.com
}

\begin{abstract}
Address term (taishoushi) is a word or a group of words used to refer to the interlocutor. Address terms used in hotels, especially five star western hotels, have special characteristic in addressing guests and also other employees. There are many factors which make speaker uses various kinds of address terms. This research aims to describe those factors. The object of this research is address term used as a term of address, that is address term used to appoint interlocutor which it cannot become an utterance without other words. In other word, term of address is a part of an uttered sentence. This research data were collected from Japanese TV drama dan movie about working life in five star hotels in Tokyo. Those are Hotelier (2007), Hotel Concierge (2015), and The Uchouten Hotel (2006). The data were collected by conducting note-taking technique to transcript the dialogue where the address term belongs to. Then, the data were classified based on speech components: setting and scene, participant, and end. In analyzing the data, there are some factors to be considered. Those are interlocutor's response, act, key, and norms. Factors in classifying participants are distance, including $u c h i$ (in-group) and soto (out-group), power, and gender. Based on the participant's relation, some social factors to determine address term are power, social distance, and gender. Situational factors may also make a speaker switches the code in using address term.
\end{abstract}

Keywords: address term, hotel communication, social factor

\section{INTISARI}

Kata sapaan (taishoushi) adalah kata yang menunjuk lawan tutur dalam situasi percakapan langsung. Kata sapaan yang digunakan di lingkungan kerja hotel, khususnya hotel berbintang lima dan bergaya barat, memiliki ciri khusus dalam hal kata sapaan yang digunakan untuk menyapa tamu dan sesama karyawan.Tujuan penelitian ini adalah untuk mendeskripsikan faktor yang mempengaruhi pemakaian kata sapaan. Penelitian ini dibatasi pada kata sapaan yang berfungsi sebagai term of address, yakni kata sapaan yang menunjuk lawan tutur dan tidak dapat berdiri sendiri sebagai tuturan tetapi menjadi bagian dari kalimat tuturan. Data penelitian ini diambil dari drama TV dan film Jepang yang menggambarkan kehidupan kerja hotel berbintang lima di Tokyo. Film yang digunakan sebagai data adalah Hotelier (2007), Hotel Concierge (2015), dan The Uchouten Hotel (2006). Data ditranskripsi kemudian dikelompokkan berdasar komponen tutur setting and scene, participant, dan end. Saat melakukan analisis, selain respon lawan tutur, faktor act, key, dan norms turut diperhatikan. Faktor yang diperhatikan dalam participant adalah distance termasuk kelompok uchi (in-group) dan soto (out-group), power, dan jenis kelamin. Berdasarkan hubungan antar partisipan tutur, faktor sosial yang mempengaruhi pemilihan kata sapaan adalah kekuasaan penutur terhadap lawan tutur, jarak sosial lawan tutur terhadap penutur, dan jenis kelamin penutur serta lawan tutur. Faktor situasi tutur juga dapat menyebabkan alih kode dalam pemakaian kata sapaan.

Kata kunci: faktor sosial, kata sapaan, komunikasi perhotelan

Panduan sitasi:

Pratiwi, D.M.I. (2020). Pemakaian Kata Sapaan (Taishoushi) di Dunia Kerja Perhotelan: Analisis Percakapan Drama TV dan Film Jepang. JLA (Jurnal Lingua Applicata), 3(2), 104-121 


\section{PENDAHULUAN}

Dalam bahasa Jepang, kata sapaan disebut taishoshi. Berdasar karakteristik pemakaiannya, Suzuki (1975) membagi taishoushi ke dalam dua golongan, yaitu 1) vocative use dan 2) pronominal use. Taishoushi golongan vocative use digunakan saat memanggil atau meminta perhatian lawan tutur, saat mengungkapkan emosi kepada lawan tutur, dan lain sebagainya. Dalam golongan vocative use terdapat pemakaian kata sapaan yang berfungsi sebagai term of address, dan calls atau summonses (panggilan) (Levinson, 1983). Perbedaan term of address dan calls adalah calls dapat berdiri sendiri sebagai sebuah tindak tutur dan calls mendahului tuturan. Sementara itu, term of address sifatnya hanya berupa sisipan kalimat, dapat terletak di awal, tengah, ataupun akhir tuturan (Levinson, 1983). Contoh kata sapaan yang berfungsi sebagai term of address adalah kata bucho pada contoh 1.

\section{Contoh 1)}

Konteks: Seorang pegawai menyapa atasan.

\section{Buchou, ohayou gozaimasu.}

'Pak Kepala, selamat pagi.'

Di lain sisi, taishoushi golongan pronominal use merujuk kepada kata sapaan yang menduduki subjek atau objek dalam kalimat. Kata sapaan golongan pronominal use merupakan pemakaian kata sapaan sebagai term of reference. Sebagai term of reference, kata sapaan dipakai untuk menunjuk partisipan tutur sesuai peran orang tersebut dalam aktivitas tuturan (Levinson, 1983). Dalam fungsinya sebagai term of reference kata sapaan dipakai untuk menunjuk peran lawan tutur terhadap penutur dalam aktivitas tuturan, yaitu sebagai orang yang berbicara, orang yang diajak bicara, atau orang yang dibicarakan. Karena berfungsi sebagai reference atau penunjuk, kata sapaan yang digunakan sebagai term of reference menjadi argumen sebuah predikat. Kata sapaan yang digunakan sebagai term of reference menduduki fungsi sintaksis dalam kalimat. Contoh kata sapaan yang berfungsi sebagai term ofreference adalah kata okaasan pada contoh 2. Pada kalimat ini, kata okaasan menduduki fungsi objek.

Contoh 2)

Konteks: Seorang anak marah kepada ibunya.

$\begin{array}{lll}\text { Okaasan } & \text { nante } & \text { kirai. } \\ \text { Ibu } & \text { partikel } & \text { benci }\end{array}$
'(Aku) benci Ibu.'

Kata sapaan adalah salah satu fitur bahasa yang digunakan pembicara untuk membentuk koneksi dengan atau jarak diri dari orang lain. Studi tentang kata sapaan dalam wacana yang terjadi secara alami berguna dalam memberikan wawasan tentang formalitas interaksi di dalam dan di antara kelompok-kelompok tertentu. Selain itu, studi tersebut menunjukkan bagaimana tingkat keakraban, kekuasaan (power), solidaritas, dan kesetaraan diberlakukan di antara kelompok-kelompok. Kata sapaan telah dipelajari dalam berbagai konteks 
termasuk percakapan santai, televisi dan tim olahraga (Parkinson, 2020).

Kata sapaan yang digunakan oleh seseorang dalam sebuah komunitas atau kelompok tertentu, biasanya tergantung pada hubungan antara pembicara dan lawan bicara dan hal tersebut merefleksikan sistem sosial budaya pada kelompok tersebut (Tobing, 2013). Zhang et al. (2018) telah melakukan analisis kata sapaan yang muncul dalam drama Jepang dan menyimpulkan bahwasannya penggunaan kata sapaan dipengaruhi oleh gender penutur dan jarak antara penutur dengan lawan tutur. Selain itu, kata sapaan juga digunakan penutur untuk mengekspresikan bagaimana hubungan dirinya dengan lawan tutur.

Masyarakat Jepang menerapkan konsep uchi (ingroup) dan soto (outgroup) dalam pergaulan. Orang-orang yang dianggap sebagai uchi (ingroup) adalah orangorang yang memiliki kedekatan secara emosional. Orang-orang yang dianggap sebagai uchi dianggap sebagai keluarga. Oleh karena itu, orang-orang yang dianggap uchi diperlakukan seperti kepada keluarga sehingga tidak ada rasa sungkan terhadap uchi. Sementara itu, orang-orang di luar uchi dianggap sebagai soto (outgroup). Orang-orang yang berada di luar grup dianggap sebagai "orang luar" atau orang lain sehingga orang-orang di luar grup diperlakukan seperti memperlakukan orang lain.

Batasan uchi dan soto tidak bersifat tetap. Wilayah uchi dan soto tidak hanya dilihat dari batasan spasial dan temporal, tetapi juga sosial dan psikologis (Quinn Jr., 1994). Wilayah tersebut dapat berubahubah sesuai situasi. Misalnya dalam situasi bekerja, rekan kerja yang tidak akrab sekalipun merupakan $u c h i$, tetapi dalam situasi di luar bekerja rekan kerja yang tidak akrab menjadi soto. Konsep uchi dan soto tentunya berpengaruh pada penggunaan kata sapaan dalam kehidupan sehari-hari di Jepang, termasuk dalam komunikasi di lingkungan kerja.

Nakane (1984) mengungkapkan bahwa di antara sesama perusahaan pun terdapat hirarki, perusahaan yang memiliki prestise di masyarakat menempati lapisan ichiryuu kaisha atau perusahaan kelas satu. Sementara itu, perusahaan yang kurang berprestise menempati lapisan yang lebih rendah. Para karyawan perusahaan kelas satu pun menempati lapisan lebih tinggi daripada para karyawan perusahaan kelas bawah. Adanya fakta tersebut memunculkan kemungkinan para karyawan perusahaan memiliki gaya komunikasi yang menunjukkan kelasnya. Gaya komunikasi ini salah satunya terwujud dalam cara menyapa atau menunjuk lawan tutur.

Berdasarkan latar belakang tersebut, penelitian ini berusaha untuk menjelaskan penggunaan kata sapaan yang digunakan di dunia kerja. Penelitian dibatasi pada dunia kerja perhotelan. Lingkungan kerja hotel dipilih sebagai lingkup kata sapaan yang akan diteliti karena diasumsikan bahwa di lingkungan kerja perhotelan, seseorang akan bergaul dengan lebih banyak orang dari berbagai kelas sosial dan melakukan dialog dalam 
berbagai situasi sehingga sapaan yang dipergunakan pun akan lebih beragam. Penelitian ini dibatasi pada kata sapaan golongan vocative use yang digunakan sebagai term of address, atau kata sapaan yang berupa sisipan kalimat, dapat terletak di awal, tengah, atau akhir tuturan. Penelitian ini akan difokuskan pada faktorfaktor yang menentukan penggunaan kata sapaan atau taishoushi di lingkungan kerja perhotelan.

\section{Komponen Tutur (Speech Component)}

Hymes (1974) mengembangkan metode penelitian yang terdiri dari situation, participants, ends (goals), acts, key, instrumentality, norms dan genre (disingkat menjadi S.P.E.A.K.I.N.G.) untuk menganalisis komponen ujaran yang digunakan dalam sebuah kelompok atau komunitas tertentu. Metode ini berfungsi untuk mempelajari cara dan pola komunikasi sebuah komunitas atau kelompok (Winston, 2012). Berikut adalah penjelasan dari S.P.E.A.K.I.N.G:

1. Situation (situasi tutur) merujuk kepada setting dan scene. Seting merupakan waktu dan tempat, serta semua lingkungan fisik saat terjadinya tuturan, sedangkan scene merupakan lingkungan psikologis atau aspek psikologis partisipan tutur. Aspek psikologis berkaitan juga dengan faktor budaya setempat karena psikologis partisipan tutur dibentuk oleh budaya mereka.

2. Participants (partisipan tutur) yaitu meliputi penutur, lawan tutur, dan pendengar atau audience. Partisipan tutur adalah semua orang yang hadir saat tuturan diucapkan. Beberapa hal yang harus diperhatikan berkaitan dengan partisipan tutur antara lain peran partisipan tutur dalam suatu peristiwa ketika tuturan diujarkan, hubungan sosial antar partisipan tutur, usia, jenis kelamin, dan lain sebagainya.

3. Ends (goals) merupakan tujuan partisipan tutur akan sebuah tuturan.

4. Acts mencakup semua tindakan yang membawa pesan bagi lawan tutur. Bentuk ujaran berkaitan dengan kata yang digunakan, bagaimana penggunaannya, dan hubungan antara apa yang dikatakan dengan topik pembicaraan

5. Key merupakan intonasi dan cara sebuah tuturan diujarkan. Key dapat berupa tindakan non-verbal, seperti kedipan mata, gestur, sikap tubuh, cara berpakaian, ataupun musik yang mengiringi

6. Instrumentality mencakup channel dan form of speech. Channel adalah alat atau instrumen yang digunakan untuk berkomunikasi, misalnya lisan, surat, telegram, atau media lainnya. Masingmasing instrumen masih harus digolongkan lagi, apakah itu dengan katakata, siulan, atau vokal yang dipanjangkan. Sementara itu, form of speech merupakan variasi linguistik yang disesuaikan dengan konteks pengguna bahasa. Form of speech juga berkaitan dengan speech style atau gaya berbicara.

7. Norms terdiri dari norms of interaction dan norms of interpretation. Norms of interaction adalah semua aturan yang mengatur bagaimana tuturan diucapkan, 
sedangkan norms of interpretation adalah bagaimana suatu interaksi diterima oleh lawan tutur dan audience.

8. Genre (G) adalah jenis tuturan, misalnya pujian pada Tuhan, doa, orasi, editorial, surat resmi, dan lain sebagainya.

Untuk memahami faktor-faktor yang menentukan penggunaan kata sapaan atau taishoushi di lingkungan kerja perhotelan, perlu dilakukan analisis komponen tuturnya terlebih dahulu. Pada penelitian ini, komponen yang diperhatikan dalam analisis terutama adalah situasi tutur (mencakup setting dan scene) dan partisipan tutur. Komponen lain juga akan digunakan dalam analisis sesuai kebutuhan dan karakteristik dialog dalam data yang ditemukan.

\section{METODE PENELITIAN}

Penelitian ini dibagi menjadi tiga tahap, yakni tahap penjaringan data, tahap analisis data, dan tahap penyajian hasil analisis data. Data penelitian diambil dari film Jepang yang diputar antara tahun 2006 sampai dengan tahun 2015 yang terdiri dari dua film seri dan satu film non seri. Film seri yang digunakan sebagai data adalah Hotelier (selanjutnya disingkat HL) (2007) dan Hotel Concierge (selanjutnya disingkat HC) (2015). Film non-seri yang digunakan sebagai data adalah The Uchouten Hotel (selanjutnya disingkat TUH) (2006). Ketiganya dipilih karena sama-sama bertemakan dunia kerja perhotelan. Ketiga film tersebut menggambarkan interaksi antara sesama karyawan hotel ataupun karyawan dengan tamu di hotel berbintang lima di kota Tokyo.
Dialog dalam film ditranskripsi, kemudian dipilih dialog yang mengandung kata sapaan. Data tersebut kemudian dikelompokkan berdasarkan bentuk kata sapaan yang digunakan ke dalam tabel. Pada setiap kelompok, dilihat ciri-ciri penutur dan lawan tuturnya (partisipan tutur). Ciri-ciri penutur dan lawan tutur yang dilihat adalah jarak sosial atau keakraban antara penutur dan lawan tutur, power penutur terhadap lawan tutur, baik dari segi usia maupun dari segi jabatan, dan jenis kelamin penutur serta lawan tutur. Faktor usia turut dipertimbangkan ke dalam power. Hal ini karena dalam masyarakat Jepang perpindahan karyawan dari satu perusahaan ke perusahaan lain frekuensinya relatif rendah sehingga usia seseorang sejalan dengan karir orang tersebut. Kemudian, pada tabel yang sama dijabarkan secara detail faktor situasional (setting dan scene) saat tuturan yang mengandung kata sapaan tersebut diucapkan.

Setelah data diklasifikasi, tahap analisis data dimulai. Kata sapaan yang diucapkan pembicara dibandingkan dengan dengan situasi tuturan. Situasi tuturan berupa situasi yang dapat dilihat secara visual ataupun yang dapat ditangkap melalui ekspresi penutur dan lawan tutur. Hasil analisis dideskripsikan secara kualitatif.

\section{HASIL DAN PEMBAHASAN}

Dari data penelitian, ditemukan 12 bentuk kata sapaan yang digunakan sebagai 
term of address di lingkungan kerja hotel seperti yang dirangkum dalam Tabel 1.

Tabel 1. Bentuk Kata Sapaan yang Berfungsi Sebagai Term of Address

\begin{tabular}{|c|c|c|}
\hline No & Bentuk kata sapaan & Contoh \\
\hline 1 & nama keluarga & $\begin{array}{l}\text { Ne Odagiri, acchi sagashite! } \\
\text { Eh Odagiri, carilah di sana! }\end{array}$ \\
\hline 2 & nama jabatan & $\begin{array}{l}\text { Fukusoushihainin, ato de ojikan itadakemasuka? } \\
\text { Wakil GM, nanti bisakah minta waktu? }\end{array}$ \\
\hline 3 & nama keluarga + -sama & $\begin{array}{l}\text { Kaiho sama, kono tabi wa makoto ni arigatou gozaimashita. } \\
\text { Ibu Kaiho, terima kasih atas kunjungannya kali ini. }\end{array}$ \\
\hline 4 & $k y a k u+-\operatorname{sama}$ & $\begin{array}{l}\text { Okyakusama, dochira e okoshi ni narimasuka? } \\
\text { Adik, hendak ke mana? }\end{array}$ \\
\hline 5 & istilah kekerabatan +- sama & $\begin{array}{l}\text { Okusama, mama ni nararerun desune? } \\
\text { Nyonya, akan jadi ibu ya? }\end{array}$ \\
\hline 6 & nama keluarga +-san & $\begin{array}{l}\text { Aa, Shukuri san, matte mashitayo. } \\
\text { Aa, Pak Shukuri, saya sudah menunggu lho. }\end{array}$ \\
\hline 7 & nama keluarga $+-k u n$ & $\begin{array}{l}\text { Honjo kun, onegai shimasu. } \\
\text { Dik Honjo, tolong, ya. }\end{array}$ \\
\hline 8 & nama diri $+-k u n$ & $\begin{array}{l}\text { Tsubasa kun, doushitano? } \\
\text { Dik Tsubasa, kenapa? }\end{array}$ \\
\hline 9 & nama diri + -chan & $\begin{array}{l}\text { Mata kite ne, Mayu chan. } \\
\text { 'Datang lagi ya, Dik Mayu.' }\end{array}$ \\
\hline 10 & minna $+(-$ sama,$-s a n)$ & $\begin{array}{l}\text { Mina sama, gokyouryoku onegaishimasu. } \\
\text { Tuan-tuan dan Nyonya-Nyonya, harap maklum. }\end{array}$ \\
\hline 11 & $\begin{array}{l}\text { nama keluarga + nama jab- } \\
\text { atan }\end{array}$ & $\begin{array}{l}\text { Osewa ni narimasu, Narusawa Shachou. } \\
\text { 'Saya mohon bantuannya, Bapak Narusawa.' }\end{array}$ \\
\hline 12 & Lain-lain & $\begin{array}{l}\text { Nani yatte runo, Ohanadanshi? } \\
\text { 'Sedang apa, Pemuda Bunga?' }\end{array}$ \\
\hline
\end{tabular}

Berikut adalah uraian untuk masing-masing bentuk kata sapaan yang ditemukan dalam data penelitian.

\section{1. nama keluarga}

Berikut ini data pemakaian nama keluarga sebagai sapaan.

Data (1)

Konteks: Penutur adalah manajer divisi pelayanan tamu (Natsuko Ueda: perempuan, 30 tahun). Lawan tutur adalah asisten manajer divisi pelayanan tamu (Kyoko Odagiri: perempuan, 27 tahun). Penutur dan lawan tutur sangat akrab. Tuturan ini terjadi di ruang binatu. Saat tuturan ini diucapkan, penutur menyuruh lawan tutur membantunya mencari anting tamu.

Asisten manajer $\quad$ : "Senpai, mada mitsu-karemasenka?"

'Mbak, masih belum bisa ditemukan?'

Manajer : "Mada. Ne Odagiri, acchi sagashite!”

'Belum. Eh Odagiri, carilah di sana!'

(HL 04: 12.06-12.18) 
Data (1) menunjukkan pemakaian kata sapaan berupa nama keluarga. Dalam data (1), lawan tutur dipanggil Odagiri oleh atasannya. Data tersebut menunjukkan kata sapaan berupa nama keluarga digunakan untuk memanggil rekan kerja dalam satu divisi.

Data lain mengenai pemakaian nama keluarga adalah data (2).

Data (2)

Konteks: Penutur adalah kepala koki (Tetsushi Tominaga: laki-laki, 39 tahun). Lawan tutur adalah concierge junior (Touko Amano: perempuan, 23 tahun). Penutur dan lawan tutur memiliki hubungan akrab. Tuturan dituturkan di aula, saat penutur memberikan kepada Amano roti tart yang dipesan tamu untuk acara ulang tahun.

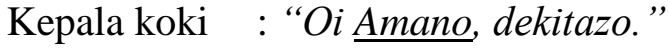

'Hei Amano, sudah jadi, lho.'

concierge: "Suggoku ii desu."

'Sungguuuh indah.'

Kepala koki : "Darou? Aji mo jishin aru kara."

'Indah, kan? Saya juga percaya diri dengan rasanya.'

(HC 09: 30.35-30.50)

Data (2) menunjukkan nama keluarga juga dapat dipakai untuk menyapa lawan tutur dari lain divisi. Namun demikian, ada kesamaan antara data (1) dengan data (2). Kesamaannya terletak pada faktor keakraban. Jika melihat ada tidaknya faktor keakraban antara penutur dan lawan tutur, kedua data tersebut menunjukkan penutur dan lawan tutur memiliki hubungan akrab.

Jika melihat hubungan sosial antar partisipan tutur, kata sapaan berupa nama keluarga digunakan untuk menyebut lawan tutur yang status sosialnya lebih rendah daripada penutur (data 1, data 2). Nama keluarga dipakai untuk menyapa lawan tutur yang bekerja dalam satu divisi ataupun lain divisi. Penutur dan lawan tutur memiliki hubungan akrab. Selain itu, status lawan tutur lebih rendah daripada penutur.

\section{2. nama jabatan}

Berikut ini data pemakaian nama jabatan sebagai sapaan.

Data (3)

Konteks: Penutur adalah GM (Kouhei Ogata: laki-laki, 45 tahun). Lawan tutur adalah wakil GM (Takehiko Iwama: laki-laki, 48 tahun). Tuturan terjadi di ruang kerja wakil GM. Ogata dan Iwama memiliki hubungan yang tidak harmonis karena Iwama menentang keputusan pemilik hotel yang mengangkat Ogata sebagai GM.

Ogata : "Fukusoushihainin, ato de ojikan itadakemasuka? Resutoran Bu no jinji no ken no hanashi.

'Wakil GM, nanti bisakah minta waktu? Tentang masalah personalia di Divisi Restoran.'

Iwama : "Hai."

'Ya.'

(HL 03: 1.33-1.46) 
Data (3) menunjukkan pemakaian nama jabatan untuk menyapa bawahan. Meskipun penutur adalah atasan langsung lawan tutur, penutur merasa sungkan terhadap lawan tutur karena hubungan keduanya tidak akrab.

Data (4)

Konteks: Penutur adalah manajer divisi pelayanan tamu (Natsuko Ueda: perempuan, 30 tahun). Lawan tutur adalah asisten manajer divisi pelayanan tamu (Kyoko Odagiri: perempuan, 27 tahun). Penutur dan lawan tutur sangat akrab. Tuturan ini terjadi di ruang binatu. Saat tuturan ini diucapkan, penutur memberi instruksi kepada lawan tutur untuk membantu mencari anting tamu.

Asisten manajer $\quad$ : "Senpai, mada mitsukaremasenka?"

'Mbak, masih belum bisa ditemukan?'

Manajer : "Mada. Ne Odagiri, acchi sagashite!"

'Belum. Eh Odagiri, carilah di sana!'

(HL 04: 12.06-12.18)

Data (4) menunjukkan pemakaian kata senpai 'kakak senior'. Senpai tidak menunjukkan jabatan secara spesifik, tetapi menunjukkan kedudukan orang yang disebut terhadap penutur. Data (4) menunjukkan senpai dipakai untuk menyapa atasan. Penutur akrab dengan atasan yang menjadi lawan tutur tersebut sehingga penutur tidak merasa ada jarak sosial dengan lawan tutur.

Berdasarkan data (3) dan data (4), kata sapaan berupa 'jabatan' dipergunakan untuk memanggil lawan tutur yang memiliki status sosial lebih tinggi ataupun lebih rendah. 'Nama jabatan' dapat digunakan untuk menyapa atasan yang akrab ataupun tidak akrab. Jika 'nama jabatan' digunakan untuk menyapa bawahan, hal ini menunjukkan bahwa penutur dan lawan tutur tidak memiliki hubungan akrab.

Sapaan berupa 'nama jabatan' juga dapat digunakan untuk menyapa tamu. Misalnya tuturan dalam data (5) di bawah ini.

Data (5)

Konteks: Penutur adalah GM Hotel Vollmond (Mihoko Katagiri: perempuan, 48 tahun). Lawan tutur adalah CEO perusahaan kosmetik yang menjadi tamu hotel (Eriko Tsubaki: perempuan, 65 tahun). Tempat terjadinya tuturan adalah di kamar tamu, saat rapat koordinasi penyelenggaraan acara ulang tahun perusahaan lawan tutur. Karena suatu masalah, lawan tutur membatalkan kontrak kerjasama dengan Hotel Vollmond. GM Katagiri berusaha supaya kontrak kerjasama tersebut tetap berjalan.

GM hotel : "Tsubaki Shachou, sore wa asu no ibento to sanjuushuunen no kyanpeen subete o hakushi ni 
modosareru to iu koto deshouka?"

'Ibu Tsubaki, apakah itu berarti Ibu membatalkan semua acara besok dan kampanye peringatan ke-30 tahun perusahaan?'

CEO : "Yakukin o haraeba mondai nai deshou?"

'Kalau membayar uang kerugian, tidak ada masalah, kan?'

GM hotel : "Desuga, Shachou.

'Tapi, Bu.'

CEO : "Ikura kakattemo kamaimasen. Ohanashi wa ijou."

'Berapapun tidak masalah. Pembicaraan selesai.'

(HC 10: 00.18-01.17)

\section{Data (7)}

Konteks: Penutur adalah asisten manajer hotel (Kyoko Odagiri: perempuan, 27 tahun). Lawan tutur adalah tamu (Yoshio Murakami dan Ayumi Murakami: sepasang suami istri, keduanya berusia sekitar 65 tahun). Tuturan ini diujarkan di kapel hotel, saat perayaan ulang tahun pernikahan lawan tutur.

Odagiri : "Murakami sama, gokekkon sanjuu shuunen omedetou gozaimasu."

'Bapak dan Ibu Murakami, selamat ulang tahun pernikahan yang ke-30 tahun.'

(HL 06: 35.18-35.34)

\section{3. nama keluarga + -sama}

Berikut ini data yang menunjukkan pemakaian sapaan nama keluarga + -sama.

Data (6)

Konteks: Penutur adalah GM hotel (Ryusuke Washio: laki-laki, 50 tahun). Lawan tutur adalah tamu hotel (Sachi Kaiho: perempuan, 40 tahun). Tuturan diujarkan di lobi, saat GM Washio mengucapkan salam perpisahan kepada tamu.

GM hotel: "Kaiho sama, kono tabi wa makoto ni arigatou gozaimashita."

'Ibu Kaiho, terima kasih atas kunjungannya kali ini.'

(HC 01: 54.51 - 55.03)
Nama keluarga + -sama digunakan oleh karyawan hotel untuk menyapa tamu. Tamu yang disapa dengan nama keluarga + -sama dapat memiliki usia lebih muda daripada penutur (data 6), ataupun usianya lebih tua daripada penutur (data 7).

Pemakaian nama keluarga + -sama tidak terpengaruh oleh faktor keakraban antara penutur dengan lawan tutur. Sapaan berupa nama keluarga + -sama dapat ditujukan kepada lawan tutur jamak, asalkan semua lawan tutur tersebut masih satu keluarga. Hal ini dapat dilihat pada data (7).

\section{4. $k y a k u+-s a m a$}

Berikut ini data yang menunjukkan pemakaian sapaan kyaku + -sama. 
Data (8)

Konteks: Penutur adalah bellboy (laki-laki, 23 tahun). Lawan tutur adalah tamu anak-anak (perempuan, 8 tahun). Tuturan diujarkan di lobi hotel, saat penutur melihat lawan tutur memasuki lobi seorang diri.

\section{Bellboy : "Okyakusama, dochira e okoshi ni narimasuka?"}

'Adik, hendak ke mana?'

(HC 05: 09.50-10.00)

Data (9)

Konteks: Penutur adalah bellboy (laki-laki, 25 tahun). Lawan tutur adalah tamu (wanita, 30 tahun). Tuturan dituturkan di depan kamar tamu. Penutur melihat lawan tutur duduk di lantai depan kamar tamu. Kemudian, penutur bertanya kepada lawan tutur.

Bellboy : "Okyakusama, douka saremashita?"

'Ibu, kenapa?'

Tamu : "Heya ni hairenai no."

'Tidak bisa masuk kamar.'

(TUH 02: 42.41-42.50)

Kata sapaan berupa okyakusama biasanya digunakan oleh karyawan hotel untuk memanggil tamu jika karyawan hotel tersebut tidak mengetahui nama tamu tersebut. Sapaan okyakusama juga dapat ditujukan kepada tamu anak-anak (data 8).

\section{5. istilah kekerabatan + -sama}

Berikut ini data pemakaian sapaan istilah kekerabatan + -sama sebagai term of address.

Data (10)

Konteks: Penutur adalah kepala koki hotel (Tetsushi Tominaga: laki-laki, 39 tahun). Lawan tutur adalah sepasang suami istri yang menjadi pelanggan restoran hotel. Suami bernama Naoki Kurata (35 tahun). Istri bernama Ayumi Kurata (30 tahun). Tuturan dituturkan di restoran hotel, saat kepala koki menyapa pelanggan tersebut.

Tominaga: "Kurata sama!"

'Bapak dan Ibu Kurata!'

Ayumi Kurata : "Ureshii! Watashi tachi no koto o oboete kuretan desune.' 'Senangnya! Masih mengingat kami, ya.'

Tominaga: "Mochiron desu to mo. (ninshin shite iru Furata sama no onaka o mite) Ah Okusama, mama ni nararerun desune? Omedetou gozaimasu."

'Tentu saja. (Melihat perut $\mathrm{Bu}$ Kurata yang sedang hamil) Ah Nyonya Kurata, akan jadi ibu ya? Selamat.'

(HC 07: 10.51 - 11.24) 
Kata kekerabatan + -sama digunakan untuk menyapa tamu. Biasanya, kata kekerabatan + -sama digunakan untuk menyapa lawan tutur jika penutur mengetahui status lawan tutur dalam keluarga, tetapi tidak dapat menyapa lawan tutur memakai nama keluarga karena ada kondisi tertentu yang menghalanginya. Kondisi yang menghalangi tersebut adalah kehadiran keluarga lawan tutur, baik secara fisik sebagai partisipan tutur maupun sebagai topik pembicaraan.

Misalnya adalah data (10). Lawan tutur adalah sepasang suami istri. Jika penutur memanggil sang istri dengan nama keluarga, maka akan terjadi kerancuan mengenai siapa yang penutur ajak bicara saat itu. Hal ini karena kedua lawan tutur memiliki nama keluarga sama. Sementara itu, penggunaan nama diri untuk memanggil lawan tutur akan dianggap tidak sopan karena status lawan tutur lebih tinggi.

\section{6. nama keluarga +-san}

Berikut ini data yang menunjukkan pemakaian nama keluarga + -san sebagai term of address.

Data (11)

Konteks: Penutur adalah GM Hotel Vollmond (Ryusuke Washio: laki-laki, 50 tahun). Lawan tutur adalah kepala concierge (Taiichi Shukuri: lakilaki, 49 tahun). Tuturan dituturkan di lobi hotel, saat penutur menyambut kedatangan kepala lawan tutur. Saat tuturan ini diujarkan adalah saat lawan tutur mulai bekerja di Hotel Vollmond.

Kepala concierge : "Suimasen, osoku natte shimatte."

'Maaf, saya terlambat.'

GM : "Aa, Shukuri san, matte mashitayo."

'Aa, Pak Shukuri, saya sudah menunggu lho.'

(HC 01: 56.10 - 57.10)

Lawan tutur dalam data (11) merupakan karyawan baru. Oleh karena itu, penutur masih merasa sungkan terhadap lawan tutur. Hal ini dibuktikan dengan sikap penutur yang tetap ramah saat lawan tutur datang terlambat. Dengan demikian, dapat dikatakan terdapat jarak sosial antara penutur dengan lawan tutur.

Data (12)

Konteks: Penutur adalah staf restoran (Aoi Hirayama: perempuan, 19 tahun). Lawan tutur adalah staf restoran (Akane Morimoto: perempuan, 19 tahun). Penutur dan lawan tutur tidak begitu akrab karena lawan tutur baru saja bergabung di restoran tersebut. Tuturan ini dituturkan di restoran, saat para staf restoran menata meja makan. Melihat lawan tutur menata sendok dengan cepat, penutur memuji lawan tutur.

Hirayama : "Morimoto san, oboeterune. Haya." 
'Mbak Morimoto, hafal ya. Cepat menatanya.'

Morimoto : "Nanimo ka mo hajimete dakara, tanoshikute."

'Karena semuanya baru pertama kali, jadi menyenangkan.'

(HL 05: 21.33 - 21.40)

Penutur merasa memiliki jarak sosial dengan lawan tutur. Hal ini karena lawan tutur masih merupakan karyawan baru sehingga penutur masih merasa sungkan terhadap lawan tutur.

Sapaan nama keluarga + -san dipakai untuk menyapa rekan kerja yang memiliki status lebih rendah (data 11) ataupun setara (data 12). Berdasarkan data (11) dan data (12), pemakaian nama keluarga +-san untuk menyapa rekan kerja yang setara atau lebih rendah menunjukkan adanya jarak sosial antara penutur dengan lawan tutur.

Berikut ini data lain mengenai pemakaian nama keluarga +- san .

Data (13)

Konteks: Penutur adalah concierge junior (Touko Amano: perempuan, 23 tahun). Lawan tutur adalah concierge senior (Kazuma Honjo: laki-laki, 27 tahun). Tuturan dituturkan di meja concierge, saat penutur memperkenalkan diri kepada lawan tutur. Saat tuturan dituturkan adalah saat penutur mulai bekerja sebagai concierge.

Amano : "Ohayou gozaimasu, Honjo san. Honjitsu zuke de ryouin bu kara idou shite kita Amano Touko desu. Kyou kara yoroshiku onegaishimasu."

'Selamat pagi, Mas Honjo. Saya Toko Amano yang hari ini pindah dari Divisi Makanan dan Minuman. Mulai hari ini mohon bantuannya.'

(HC 01: 00.53 - 01.08)

Nama keluarga + -san dipakai untuk menyapa lawan tutur yang memiliki status lebih tinggi, khususnya atasan atau karyawan senior. Nama keluarga + -san tidak dapat dipakai untuk menyapa atasan yang biasa disapa dengan nama jabatan. Penulis tidak menemukan pemakaian kata sapaan nama keluarga + -san untuk menyapa tamu.

\section{7. nama keluarga $+-k u n$}

Berikut ini data yang menunjukkan pemakaian sapaan nama keluarga $+-k u n$.

Data (14)

Konteks: Penutur adalah GM hotel (Ryusuke Washio: laki-laki, 50 tahun). Lawan tutur adalah concierge (Kazuma Honjo: laki-laki, 27 tahun). Tuturan dituturkan di lobi, saat penutur memerintahkan lawan tutur supaya mengantar tamu sampai ke kamar. : "Honjo kun, onegai shimasu." 'Dik Honjo, tolong, ya.'

(HC 06: 00.39 -01.02) 
Data (15)

Konteks: $\quad$ Penutur adalah CEO (Kojiro

Kitano: laki-laki, 63 tahun). Lawan tutur adalah staf (Kyoko Odagiri: perempuan, 27 tahun). Tuturan ini dituturkan di kantor saat penutur mengangkat lawan tutur menjadi asisten manajer.

CEO : "Odagiri kun, kyou kara asisutanto manejaa. Kitai shite ruyo."

'Dik Odagiri, mulai hari ini kamu asisten manajer. Saya berharap padamu, lho.'

Staf : "Arigatou gozaimashita." (ojigi)

'Terima kasih.' (membungkukkan badan)

(HL 01: 46.38 - 46.44)

Berdasarkan data tersebut, lawan tutur yang disapa memakai nama keluarga + -kun dapat berjenis kelamin laki-laki (data 14) ataupun perempuan (data 15). Sapaan berupa nama keluarga $+-k u n$ digunakan untuk menyapa bawahan.

Berdasarkan data 14 dan data 15 , terdapat keakraban antara penutur dan lawan tutur. Oleh karena itu, nama keluarga $+-k u n$ dipakai untuk menyapa bawahan, selama penutur tidak merasa ada jarak antara penutur dengan bawahan tersebut.

\section{8. nama diri $+-k u n$}

Berikut ini data yang menunjukkan pemakaian sapaan nama diri $+-k u n$.
Data (16)

Konteks: Penutur adalah concierge (Touko Amano: perempuan, 23 tahun). Lawan tutur adalah tamu anakanak (Tsubasa Kaiho: laki-laki, 5 tahun). Tuturan ini dituturkan di lobi, saat penutur melayani lawan tutur.

Anak tamu : "Konsheruju san!”

'Mbak!'

Concierge : "Tsubasa kun, doushitano?"

'Dik Tsubasa, kenapa?'

Anak tamu : "Konsheruju san, boku no onegai mo kiite kureru?"

'Mbak, apakah akan mendengarkan permintaanku juga?'

Concierge : "Un, nani kana?"

'Ya, apa itu ya?'

(HC 01: 26.27 - 27.30)

Nama diri + -kun dipakai untuk menyapa tamu yang masih berusia anakanak, dan berjenis kelamin laki-laki. Karyawan hotel dapat menyapa tamu anakanak menggunakan nama diri + -kun meskipun karyawan hotel tidak akrab dengan tamu anak-anak tersebut. Penutur yang merupakan karyawan hotel memanggil tamu anak-anak memakai sapaan nama diri + -kun supaya lebih akrab dengan tamu anak-anak tersebut.

\section{9. nama diri + -chan}

Berikut ini data yang menunjukkan pemakaian sapaan nama diri + -chan. 
Data (17)

Konteks: Penutur adalah concierge (Kazuma Honjo: laki-laki, 27 tahun). Lawan tutur adalah tamu anak-anak (Mayu Morimura: perempuan, 7 tahun). Tuturan dituturkan di lobi, saat concierge mengucapkan salam perpisahan kepada tamu.

Concierge : "Mata kite ne, Mayu chan."

'Datang lagi ya, Dik Mayu.'

(HC 03: 45.41 - 46.04)

Berdasarkan data (17), sapaan berupa nama diri + -chan digunakan untuk menyapa tamu anak-anak dan berjenis kelamin perempuan. Penutur menyapa tamu anakanak berjenis kelamin perempuan dengan kata sapaan nama diri + -chan untuk membuat penutur akrab dengan lawan tutur.

\section{0. minna + (-sama, -san)}

Berikut ini data yang menunjukkan pemakaian minna sebagai term of address.

Data (18)

Konteks: Penutur adalah asisten manajer (Tokiko Yabe: perempuan, 40 tahun). Lawan tutur adalah dua orang anak buah penutur. Tuturan ini dituturkan di aula kosong dalam acara perpisahan salah satu karyawan. Tuturan ini dituturkan saat penutur memberi perintah kepada lawan tutur.

Asisten manajer $\quad$ : "Hai, minna! Shigoto! Shigoto! Ruum saabisu kara ne. Gurobo Suito, meeku appu no fuda ga dete rutte." 'Yaa, kalian semua! Kerja! Kerja! Ini dari divisi room service. Katanya, keluar kartu perintah untuk merapikan kamar dari kamar Gurobo Suite.'

(TUH 01: 18.40 -18.52)

Berdasarkan data (18), minna merupakan nomina yang dipakai untuk menyapa lawan tutur jamak. Sapaan minna dipakai untuk menyapa bawahan. Biasanya, bawahan yang dipanggil minna memiliki hubungan dekat dengan penutur atau masih satu divisi dengan penutur.

Data (19)

Konteks: Penutur adalah concierge (Kazuma Honjo: laki-laki, 27 tahun). Lawan tutur adalah semua tamu hotel. Tuturan diujarkan di hotel saat penutur memberi pengumuman kepada semua tamu tentang adanya keadaan darurat.

Concierge : "Kinkyuu jitai desu. Ninshin chuu no Kurata sama no okusama ga hassui nasaremashita. Kyuukyuutai touchaku made oheya de ishi no Onodera sama ga shinsai shite kudasaimasu. Mina sama, gokyouryoku onegaishimasu."

'Terjadi keadaan darurat. Istri Tuan Kurata yang sedang hamil mengalami pecah ketuban. Sampai tim medis tiba, Dokter On- 
odera akan membantu persalinan di kamar. Tuan-tuan dan NyonyaNyonya, harap maklum.

(HC 07: 34.06 - 34.54)

Nomina minna dipakai untuk sapaan kepada lawan tutur jamak. Sementara itu, akhiran nominal -sama dipakai untuk menyapa lawan tutur yang memiliki status sosial lebih tinggi dan berasal dari luar hotel, dalam konteks perhotelan adalah tamu. Dengan demikian, sapaan minna + -sama dipakai untuk menyapa tamu yang berjumlah jamak.

Data (20)

Konteks: Penutur adalah concierge junior (Touko Amano: perempuan, 23 tahun). Lawan tutur adalah karyawan hotel dari berbagai divisi dan berbagai posisi. Semua lawan tutur adalah kawan akrab penutur. Salah satu kawan akrab yang posisinya lebih senior daripada penutur adalah Yudai Tango (laki-laki, 29 tahun). Tuturan diujarkan di ruang divisi Florist, saat lawan tutur sedang membantu mempersiapkan bunga untuk pesta yang diadakan oleh penutur untuk tamu.

\begin{tabular}{|c|c|}
\hline Amano & $\begin{array}{l}\text { : "Mina san! Arigatou gozai- } \\
\text { masu." }\end{array}$ \\
\hline & 'Teman-teman! Terima kasih.' \\
\hline Tango & $\begin{array}{l}\text { : "Betsu ni omae no tame ni } \\
\text { yatte runjane." }\end{array}$ \\
\hline
\end{tabular}

'Kami melakukan ini bukan untuk kamu.'

(HC 01: 38.21 - 38.53)

Sapaan yang dipakai dalam data (20) adalah mina san karena beberapa lawan tutur memiliki status lebih tinggi daripada penutur, ada pula yang berasal dari lain divisi meskipun semua lawan tutur akrab dengan penutur. Namun demikian, penulis tidak menemukan pemakaian kata sapaan mina san untuk menyapa tamu.

\section{1. nama keluarga + nama jabatan}

Berikut ini data pemakaian nama keluarga + nama jabatan sebagai sapaan.

Data (22)

Konteks: Penutur adalah GM hotel (Mihoko Katagiri: perempuan, 48 tahun). Lawan tutur adalah CEO perusahaan kosmetik yang menjadi tamu hotel (Eriko Tsubaki: perempuan, 65 tahun). Tuturan terjadi di lobi, saat penutur menyambut lawan tutur.

GM : "Tsubaki Shachou, souritsu sanjuu shuunen omedetou gozaimasu." (hanataba wo ageru)

'Ibu Tsubaki, selamat atas ulang tahun berdirinya perusahaan yang ke-30.' (sambil menyerahkan buket bunga)

Tamu : "Maa. Arigatou. Katagiri san, watashi no suki na hana oboete kudasattano." 
'Wah, terima kasih. Mbak Katagiri, masih ingat bunga favorit saya.'

(HC 09: 00.08 -00.46)

Sapaan berupa nama keluarga + nama jabatan dipakai untuk menyapa tamu.

Data (23)

Konteks: Penutur adalah GM baru (Mihoko Katagiri: perempuan, 48 tahun). Lawan tutur adalah CEO hotel (Eiichi Narusawa: laki-laki, 65 tahun). Tuturan terjadi di ruang kerja CEO, saat CEO menyambut kedatangan Katagiri. Saat tuturan diujarkan, Katagiri baru saja masuk bekerja di Hotel Vollmond. Ia direkrut secara khusus oleh CEO untuk memperbaiki manajemen hotel. Sebelum direkrut oleh CEO Narusawa, Katagiri bekerja di hotel ternama di Inggris.

CEO : "Matte iya yo, Katagiri kun." 'Sudah saya tunggu lho, Dik Katagiri.'

GM : "Osewa ni narimasu, Narusawa Shachou."

'Saya mohon bantuannya, Bapak Narusawa.'

(HC 01: $20.15-22.15)$

Data (24)

Konteks: Penutur adalah GM senior (Ryusuke Washio: laki-laki, 50 tahun). Lawan tutur adalah GM junior (Mihoko Katagiri: perempuan, 48 tahun). Tuturan ini diujarkan di ruang kerja CEO, saat rapat. Hubungan antara GM Washio dan GM Katagiri tidak harmonis karena mereka selalu berbeda pendapat. GM Katagiri adalah mantan istri GM Washio.
GM Katagiri : "Hitotsu yoroshii deshouka?"
'Bolehkah bertanya satu hal?'

GM Washio : "Nan deshou, Katagiri Zeneraru Manejaa?"

'Apa itu, Ibu Katagiri?'

(HC 03: 03.59 - 04.11)

Data (23) dan data (24) menunjukkan pemakaian sapaan nama keluarga + nama jabatan untuk menyapa rekan kerja. Berdasarkan data tersebut, nama keluarga + nama jabatan dipakai untuk menyapa lawan tutur yang status sosialnya lebih tinggi (data 23) dan lawan tutur yang status sosialnya lebih rendah (data 24).

Penutur dalam data (23) adalah karyawan baru sehingga masih merasa sungkan terhadap lawan tutur. Adanya perasaan sungkan menjadi petunjuk bahwa penutur secara psikologis merasa memiliki jarak dengan lawan tutur. Sementara itu, penutur dalam data (24) juga merasa memiliki jarak dengan lawan tutur. Jarak itu dikarenakan hubungan penutur dan lawan tutur tidak harmonis. Berdasarkan penjelasan tersebut, pemakaian nama keluarga + nama jabatan untuk menyapa sesama karyawan menunjukkan adanya jarak sosial antara penutur dengan lawan tutur. 


\section{Lain-lain}

Berikut ini data penggunaan kata sapaan yang tidak termasuk dalam semua kategori di atas.

Data (25)

Konteks: Penutur adalah staf divisi binatu (Misaki Sawatari: perempuan, 45 tahun). Lawan tutur adalah staf divisi Florist (Yudai Tango [laki-laki, 29 tahun] dan Riku Ikegami [laki-laki, 23 tahun]. Penutur dan lawan tutur akrab. Tuturan dituturkan di depan ruang divisi Florist saat penutur melewati divisi Florist.

Kepala koki : "Nani yatte runo, Ohanadanshi? "'
'Sedang apa, Pemuda Bunga?'

(HC 03: 17.48 - 18.07)

Sapaan dalam data (25) adalah ohanadanshi. Ohanadanshi merupakan kata jadian. Ohanadanshi memiliki akar kata hana 'bunga' dan danshi 'pemuda'. Kemudian, dilekati awalan $o$-. Ohanadanshi dimasukkan ke dalam kategori lain-lain, karena terdiri atas dua nomina sebagai akar kata dan awalan. Kemudian, akar kata dan awalan tersebut bergabung menjadi satu kata tunggal yang tidak dapat dipisahkan. Kata ohana 'bunga' jika berdiri sendiri tidak dapat dipakai untuk menunjuk orang. Kata danshi 'laki-laki' jika berdiri sendiri menunjukkan laki-laki secara umum dan tidak dapat dipakai sebagai sapaan. Selain ohanadashi masih terdapat bentuk sapaan lain yang tidak dapat dimasukkan ke kategori sebelumnya.

Pemakaian kata sapaan berupa julukan merupakan bentuk tindak tutur ilokusi kategori direktif. Penutur memilih kata sapaan berupa julukan dengan tujuan bercanda. Penutur berharap lawan tutur tertawa mendengar dirinya dipanggil ohanadanshi.

\section{KESIMPULAN}

Faktor yang mempengaruhi pemilihan kata sapaan adalah faktor sosial dan situasional. Faktor sosial terdiri atas usia lawan tutur, hirarki lawan tutur terhadap penutur, keakraban, kesamaan grup (uchi atau soto) dalam hal ini kesamaan institusi kerja. Faktor sosial lainnya adalah jenis kelamin penutur atau lawan tutur. Faktor situasional terdiri atas setting and scene serta tujuan tuturan. Setting and scene terdiri atas tempat terjadinya tuturan, situasi saat tuturan terjadi, topik pembicaraan berupa masalah pekerjaan atau masalah pribadi. Selain itu, penutur juga mempertimbangkan kehadiran orang lain saat tuturan terjadi.

Kata sapaan tertentu juga dapat dipakai sebagai tindak ilokusi direktif. Kata sapaan tersebut adalah kata sapaan yang berupa julukan. Contohnya adalah ohanadanshi 'lelaki bunga'.

Penelitian ini menunjukkan hotel berbintang lima di Tokyo hanya memakai kata sapaan nama keluarga + -sama untuk menyapa tamu. Sementara itu, pemakaian kata sapaan nama keluarga + -san untuk menyapa tamu tidak ditemukan. Untuk 
menyapa atasan dipakai kata sapaan nama keluarga + -san atau nama jabatan.

Pemakaian kata sapaan di bidang pekerjaan lain tentunya akan berbeda dengan kata sapaan di hotel. Kata sapaan yang dipakai di hotel berkelas rendah tentunya juga akan berbeda dengan kata sapaan yang dipakai di hotel berbintang lima. Oleh karena itu, penelitian masih perlu dilakukan lebih banyak.

\section{DAFTAR PUSTAKA}

Hymes, D. (1974). Foundations in Sociolinguistics: An Ethnographic Approach. University of Pennsylvania Press.

Levinson, S. C. (1983). Pragmatics. Cambridge University Press.

Nakane, C. (1984). Japanese Society. Charles, E. Tuttle., Co.

Parkinson, J. (2020). On the use of the address terms guys and mate in an educational context. Journal of Pragmatics, 161, 81-94. https://doi.org/10.1016/j.pragma.2020. $\underline{03.003}$

Quinn Jr., C. J. (1994). The Terms Uchi and Soto as Windows on a World. In
M. J. Bachnik \& C. J. Quinn Jr. (Eds.), Situated Meaning: In-side and Outside in Japanese Self, So-ciety and Language. Princeton University Press. Suzuki, T. (1975). Kotoba to Bunka. Iwanami Shoten.

Tobing, R. L. (2013). How to Say "hello" in Indonesian Language (Teaching Indonesian Address Term). Procedia Social and Behavioral Sciences, 103, 449-458.

https://doi.org/10.1016/j.sbspro.2013. $\underline{10.359}$

Winston, B. (2012). "Dell HymesS.P.E.A.K.I.N.G."

http://tiemcenter.org/wpcontent/uploads/2012/05/Dell-HymesSPEAKING.pdf.

Zhang, W., Liu, S., \& Kawaguchi, R. (2018). A Study on Gender Differences in Use of Addresseereferring Terms: Analyzing Conversations in TV Dramas. Bulleting of the Bunkyo University Graduate School of Language and Culture, 4, 31-53. http://id.nii.ac.jp/1351/00007321/ 